\title{
DISILLUSION, DILEMMA AND DIRECTION: THE ROLE OF THE UNIVERSITY IN PROPERTY RESEARCH
}

\author{
SPIKE BOYDELL \\ University of Technology, Sydney
}

\section{ABSTRACT}

At a time when academics in the vocational built environment disciplines find themselves in an employment environment with an increasing emphasis on research output and impact, there is conflicting push for 'reality' from the industry that our graduates will serve. There is resultant disillusionment from both academe and industry. Add to this the expectation from our accreditation bodies that lecturing staff, including part-time faculty with extensive industry expertise, must have a strong research profile and the dilemma is compounded. This keynote address presented at the $13^{\text {th }}$ PRRES conference in Fremantle over 21 - 24 January 2007 will challenge industry, academe, and our professional institutions to come together and find consensus on how we best balance the multiple expectations on our university faculties to serve society in the built environment arena.

Keywords: Property, research, education, academe, collaboration, RQF, ARC.

\section{PREAMBLE}

Firstly, I acknowledge the customary guardians of this land, the Noongar people. The importance of the role of the guardians to people, place, and property, and particularly the issue of our respective values and beliefs is a theme that provides an overarching narrative to my address.

Secondly, I acknowledge the Australian Property Institute (API) for kindly inviting me to share my perceptions on the research challenges and opportunities that the Pacific Rim Real Estate Society (PRRES) community face in these dynamic times. I also thank the API National President, Ms Marcia Bowden, for her kind introduction. As a recent Fellow of the API, joining under the Property Leaders initiative in early 2006, I have been pleased to assist senior members on various government liaison initiatives and look forward to being more active in the months and years ahead.

My third acknowledgement is to the PRRES community. I would like to express my personal thanks to Dr Greg Costello and his team at Curtin in hosting this event. I have enjoyed being an active member of PRRES since attending my first conference in Sanctuary Cove in 1994. I have always found PRRES to be a collegial and supportive grouping of kindred scholars as we have variously navigated our respective research 
journeys. I find it humbling to have been asked to present a plenary amongst my peers, mentors, current and former colleagues, many of whom I am also pleased to count amongst my friends. To be true to friends, I hold that it is important to share our deeper insights and concerns.

The pursuit of truth has "always demanded that intellectuals question the sacred and mention the unmentionable" (Furedi, 2004). It is important to keep in mind that one of the roles of a university is to question conventional truth. This is not to say that airing such views solves or reconciles any given challenge, but rather it allows seeds of thought to be planted that can be mused over in the days, months, and years ahead. Given that I am amongst friends, there is a caveat to this paper in that some of what I may say in the next forty minutes will confront or even offend certain of your sensitivities. Having said that, I hope that the reflections in this paper will allow us to progress a conversation about our 'condition'; as with every conversation there is no promise of a final agreement (Appiah, 2006). Borrowing from Appiah, "the word 'conversation' in this context refers not only to literal talk but rather as a metaphor for engagement with the experience and ideas of others... Conversation doesn't have to lead to consensus about anything, especially not values; it's enough that it helps people to get used to one another".

No conversation like this, as Appiah warns us, can progress without the potential for three kinds of disagreement about values: failing to share a vocabulary of evaluation; interpreting the same vocabulary differently; and, giving the same values different weights or importance. Irrespective of whether I present you with facts or values, there is no guarantee that I will be able to persuade you individually or collectively of my view or the validity of the concerns that I will share. "The Positivist holds that with facts, when we disagree, one of has the truth, one of is underwritten by the ways things are, whereas with values there is nothing to underwrite our claims" (Appiah, 2006). Yet, these are times of changing academic values in the land of the valuer and property professional.

There is common acceptance that academics have three core areas of activity: teaching, research and community service. Corden exchanges community service for 'public discourse' and adds 'scholarship' (Corden, 2005), which arguably is intertwined at the research/teaching nexus and the role of the public intellectual if, according to Furedi (2004), such an individual endures. This is an issue for PRRES, the API and our respective academic groupings to tackle as we lack public intellectuals in our discipline, which does not help our cause. Yes, we have some media savvy peers and some profiled gentleman scholar adjunct members of faculty... but many of our colleagues are seemingly shy at profiling their expertise (including the findings of research shared at conferences such as this) in the public arena. Some of my colleagues have referred to it as the 'tall poppy' syndrome, but in many cases it relates to insecurity that we may be cut down by our peers and the community we serve. Lesson: we need overcome such frailties and better promote our scholarship. We also need media presence at PRRES. 


\section{SCHOLARSHIP POST DAWKINS}

Boyer pushed for an alternative conceptualisation of academic work, suggesting that individual institutions and individual academics should adapt to a different balance of what he referred to as the 'four scholarships' (Boyer, 1990):

(a) Scholarship of discovery - original research and the advancement of knowledge;

(b) Scholarship of integration - connectivity of ideas across disciplinary boundaries;

(c) Scholarship of application - assembling knowledge with interaction between intellectual and 'real world' problems of practice; and,

(d) Scholarship of teaching - transforming knowledge through closing the gap between the scholar's understanding and the student's learning.

Ramsden identifies that the four are difficult, if not impossible, to quantify (Ramsden, 1998). Corden argues that most students expect the teaching component to be vocational training, including fields where the "intellectual demands are very limited" (Corden, 2005). He leaves unanswered the challenging question, that perhaps we should address at PRRES, as to where the line should be drawn between TAFE training and university-level training. The professions seem comfortable that the Dawkins Revolution of the late 1980s and early 1990s resulted in their education programmes being elevated from Diploma to Degree entry into the profession. Despite the supposed 'dumbing down' of university education, there is no indication that the professions want to revert to sub-degree entry via TAFE, albeit that the RICS globally added an alternative 'extra' technician entry level to, in part, accommodate the potential of an increased membership with diverse education experience.

Pre-Dawkins there was a clearer four-tier hierarchy with universities above the colleges of advanced education and technology institutes, with the TAFE (technical and further education) institutes sitting below these two. The argument follows that, generally speaking, there is a breadth rather than depth in vocational undergraduate teaching programmes [which has ramifications on subsequent research potential].

The only certainty in the university sector is the certainty of change. By their nature, universities should be dynamic. Under the leadership of John Dawkins, then Commonwealth Minister of Education, the 'Binary System' of higher education in Australia came under significant review in 1988. At that time Australia had 19 Universities 'proper' (to use Max Corden's phrase) and the 'others', which comprised 57 Colleges of Advanced Education and Technology. By completion of the review in 1992, the Unified National System consisted of 36 (later 39) universities. Significant in this process is that subsequently staff at former Colleges of Advanced Education have been expected to 'do research' (Corden, 2005). The growing pains of the post Dawkins universities in Australia are shared by many of their counterparts in the UK, which saw 32 polytechnics attain university status in 1992. 
Corden suggests that the emphasis on research is relatively new in Australian universities, with Rowe expressing concern over a general lack of it back in 1960 (Rowe, 1960), albeit that research is now the hallmark of a 'real' university in Australia (Corden, 2005). Funds for research come predominantly from the Commonwealth government. If industry seeks to guide the research agenda, then they need to come to the funding party either individually or through ARC partnership and university linkage models and/or through the co-operative research centre (CRC) model. Australian universities in general and the technical universities in particular, lack the private endowments that serve to fund research in counterpart institutions in the US.

\section{THE RQF AND THE ARC}

There is a risk that the expectations of the Research Quality Framework (RQF) that is driving research at Australian Universities (akin to its UK RAE - Research Assessment Exercise counterpart) could be the death knell for conferences like PRRES. I say this given the tightening of university funding coupled with a much tighter outcomes oriented research agenda. The RQF (Commonwealth Department of Education Science \& Training, 2006) is currently one of the most critical drivers in Australian universities, and I do not believe that any of the Australian universities represented here at PRRES are at all well placed to deal with it. My view is that PRRES has an important leadership role to play, as do our professional body sponsors, the RICS yesterday and the API today, in working with their university and industry / government partners to determine the direction that academic research in the property and land economy sectors will take in these changing times.

The Expert Advisory Group for the Research Quality Framework model in Australia has agreed that, for the purposes of the RQF, the definition of research would be consistent with a broad notion of research and experimental development (R\&D) (EAG, 2005). They relied on the OECD Frascati Manual view of R\&D as comprising "creative work undertaken on a systematic basis in order to increase the stock of knowledge, including knowledge of man, culture and society, and the use of this stock of knowledge to devise new applications" (OECD, 2002). This is augmented by the Australian Bureau of Statistics (ABS) view that further classifies R\&D into four types of activity: "pure basic research; strategic basic research; applied research including new ways of achieving specific and predetermined objectives such as clinical practice; and experimental development including creative work and performance insofar as they directly relate to original basic and applied research" (ABS, 1998).

A core source of competitive research funding is through an Australian Research Council (ARC) Discovery or Linkage grant. The objective of Discovery grants is to "develop and maintain a broad foundation of world-class research across a wide range of disciplines" (ARC, 2006). Whereas Linkage grants are designed to "encourage and extend cooperative approaches to research and improve the use of research outcomes by 
strengthening links within Australia's innovation system and with innovation systems internationally". There are four national research priority areas:

- an environmentally sustainable Australia;

- promoting and maintaining good health;

- frontier technologies; and,

- safeguarding Australia.

Only three ARC grants were awarded in the 'Architecture, Urban Environment and Building' (310000) category in the 2005 funding round, which reflects on the evolving nature of research in our discipline.

\section{OUR IMMATURE RESEARCH DISCIPLINE}

The nature of our immature research discipline merits further explanation. "Postgraduate students in the built environment, as a general rule, because of the structure of their first degree, have no extensive training in a research discipline, have no well-developed understanding of a theoretical framework, have never worked at the 'frontiers of knowledge', have never had reason to critically analyse new theoretical developments or current research methods and have never been required to develop much skill in increasing the sum of knowledge" (Runeson and Skitmore, 1999). Part of the challenge is that the vocational nature of our undergraduate programmes expose students to a diversity of fundamental disciplines (see Figure 1), as indeed they should - but unfortunately the demands of a broad undergraduate programme means that few, if any, of the subjects are developed above introductory level. In contrast, undergraduates in the sciences, economics, or medicine are exposed to strong theoretical frameworks, which build as the course of study develops, and by the later stages they are "working on the edge of development in their discipline". In contrast, our graduates leave armed with the skills that (supposedly) make them good professionals rather than good researchers. 


\section{Figure 1: Fundamental disciplines for real estate involvement (adapted from Roulac 2001)}

\begin{tabular}{|l|l|l|}
\hline Accounting & History & Project Management \\
\hline Appraisal and Valuation & History of Design & Psychology \\
\hline Architecture & History of Science & Public Administration \\
\hline Archaeology & Humanities & Qualitative Methods \\
\hline Behavioural Economics & Information Theory & Quantitative Methods \\
\hline Computer Science & Institutional Economics & Regional Planning Theory \\
\hline Computer Technology & Investment & Religious Studies \\
\hline Construction Management & Law & Sales \\
\hline Decision Science & Management & Science \\
\hline Decision Theory & Management Science & $\begin{array}{l}\text { Sociology and } \\
\text { Anthropology }\end{array}$ \\
\hline Ethics & Managerial Accounting & Spirituality \\
\hline Environmental Science & Managerial Economics & Strategy \\
\hline Economics & Marketing & Statistics \\
\hline Engineering & Philosophy & Transportation \\
\hline Finance & $\begin{array}{l}\text { Planning \& Control } \\
\text { Systems }\end{array}$ & Urban Land Economics \\
\hline Geography & Political Science & Urban Planning Theory \\
\hline
\end{tabular}

I would argue that the breadth of our programmes and the emphasis on technical skills by industry and the profession are limiting our potential to push the boundaries of understanding and in many cases limit potential. Unfortunately, the preponderance of taught post-graduate courses that are financially robust for the university does little to address the limitation.

\section{THE ROLE OF THE ACADEMIC}

Those of us in universities are confronted by what Nillsen calls "the trivialisation of the role of the academic" (Nillsen, 2004). As academics, we are in a difficult place especially in the relatively young post Dawkins university disciplines of the built environment. Described as "the marginalisation of intellectual passion in higher education [it is] the unintended consequence of a new ethos of managerialism that dominates intellectual and cultural life..." (Furedi, 2004). We have to accept, as Saunders argues, that the "real work of the university is whatever suits the universities interests..." and we have management structures in place to transfer 'directives' to those of my colleagues who find themselves at the chalk face (Saunders, 2006). 
Managers, rather than academics, are left to determine what the real work of the university is. Higher education teaching has been commoditised and, as Saunders argues, finds its integrity compromised by "priority being given to what is vocational rather than intellectual, to 'dumbing down', and to student evaluation of academic staff'. This apparent 'dumbing down' of our higher education is not, as Furedi reminds us, limited to Australia as it is also the contemporary situation in the UK and US (Furedi, 2004).

"The idea that the university - any university - should have as its main goal the pursuit of truth has been slowly eroded in favour of the notion that it ought primarily to be an instrument of micro-economic change" (Saunders, 2006). The dominance of business schools as the most financially viable faculty of the contemporary university supports this view, with a corresponding decline in the humanities and foreign languages at many universities. Interestingly, from a teaching perspective, those of us in built environment schools now have the opportunity to play our vocational expertise as a strength, but clearly need to complement that 'relevant' teaching capability with scholarship, intellectual rigour and research to provide leadership and guide future innovation for the industry.

Coady and Miller suggest "if we give up on truth and the possibility of objectivity, we abandon the intellectual life for fantasy, power-plays and propaganda" (Coady and Miller, 1993). "The displacement of the thinker by the expert has also weakened the publics interest in debating big issues"... it is difficult for intellectuals to both find their voice and find an audience in this climate (Furedi, 2004). Returning to my earlier point, complacency, conformism, and conservatism are evident among professional academics. The academic professional has displaced the vocation of the intellectual. "Most academics tend to be intelligent professionals and astute experts, who sadly are not culturally equipped to play the role of the public intellectual". Knowledge has become vested in the specialist, the disciplinarian and the expert rather than the public. As objective knowledge appears to have technical character, the experts and technicians tend to displace those looking for more profound insights.

Given the relative immaturity, we do not have a robust history of evolving thought and theory within our built environment disciplines - instead, as is demonstrated by the nature of many papers presented at this PRRES conference, we have an emphasis on technical, and to a degree scientific, content. Perhaps given our short heritage, in many cases coming from post Dawkins universities, we have felt constrained, downtrodden, undervalued, ill equipped, or insecure in the pursuit of ideas.

Undertaking a genuine journey of intellectual discovery runs the risk of being labelled as elitist or irrelevant. "Rather, intellectuals inside and outside the university must face up to the uncomfortable truth that they risk making themselves irrelevant if they allow institutional pressure to dominate their work" (Furedi, 2004). Intellectuals need to reclaim their authority (and should be supported by the professions and industry in so doing). Lesson: there is a battle to be waged for ideas... and we need a strategy to transform. 
The institutional pressure has ensured that universities are one of the most intensely audited institutions in society. McCaffer addressed the UK Research Assessment Exercise and suggested the likely impact that the Research Quality Framework would have on Australian universities (McCaffer, 2005). There is a view that external auditing erodes the autonomy of the university. Academics are now expected to work according to criteria established by the external adviser, civil servant and politician. Whilst at one level auditing provides reassurance and confidence, ultimately it transforms how a university works, as any of us who have experienced an Australian Universities Quality Assurance (AUQA) audit of our institutions can testify. Lesson: extraneous norms replace those particular to a discipline.

\section{VALUING KNOWLEDGE}

"Despite tensions, valuing knowledge and being interested in its application can co-exist. Pure and applied research, and abstract and empirical theory can thrive so long as the authority of knowledge is accepted in society" (Furedi, 2004). If we ask the question, "does industry and the profession respect and accept the knowledge of the university?" we may be uncomfortable with the response. Indeed, the advertising by the Property Council for their own courses states: "Our programs deliver practical learning that counts... not academic theories" (PCA, 2006). This, followed by Bernard Salt's trite attack on academe in the subsequent issue (Salt, 2006) and Stephanie McDonalds confused report on property (marketing) research (McDonald, 2006), prompted a useful discussion with Peter Verwer, the CEO of the Property Council of Australia... the well informed voice behind "The Voice of Leadership". Whilst several members of PRRES have an established relationship with the Property Council (seeking data or minor funding), seemingly I was the first to engage Peter by asking what it was that we as academics could do for Property Council. As property academics, we collectively have the skills and intellect to cost effectively tackle the big problems on the direction of property that are beyond the capacity of the PCA or its member companies. PCA also have an influential advocacy role that needs grounding on well-executed, appropriate and timely research. Lesson: we have to work hard to break down perceptions.

\section{THE PACE OF CHANGE}

I suggested that [collectively] we are not well prepared for the RQF. There are several reasons for this, which may be best illustrated by sharing my experiences as one of more recent professors in the PRRES region and, to the best of my knowledge the only one with a solely research mandate. I am twelve months into my role as research professor of the Built Environment at the University of Technology Sydney (UTS). It may sound like the dream job in academe to some of you; on reflection it has been a curious, challenging, stimulating and sometimes lonely year. I have, however, had more time to dwell, reflect and become preoccupied than most of you on the multiple expectations that confront research in our respective discipline(s). I have also spent a certain amount of my time with my finger in the dyke trying to figure out how to respond to these multiple 
expectations, juggling the skill sets that we bring to the arena. Unfortunately, the fact is that few, if any, of us have the Department of Education, Science and Training (DEST) and Australian Research Council (ARC) track record that will ensure our survival as academic disciplines and departments (or in many cases even as academics) beyond the 2012 round of the RQF unless we change our way of thinking about what it is to be a property academic in the contemporary university. Lesson: we need to change, and we need to adapt faster than we are used to.

For my part, I am associated with a School of the Built Environment within a Faculty of Design, Architecture and Building. It was the transdisciplinary nature of my role in a multi-disciplinary creative Faculty that attracted me to my current role. The School of the Built Environment comprises the four kindred disciplines of property, construction, project management, and urban planning. In Australia, as Runeson and Skitmore (1999) identify, the first three have a very short research heritage only elevating to university level in the post-Dawkins era. Urban planning, with its links to urban geography and urban social theory, is a far better regarded research discipline within the pre-Dawkins universities - but in contrast has more difficulty in attracting student numbers.

Those of us who found ourselves in the 'new' post-Dawkins universities (or their counterpart new 'former polytechnic' universities in the UK) have known since 1991/1992 that the primarily teaching role would take on a research emphasis. For this reason, many of us went through the enormous personal challenge of pursuing in-service part-time doctoral study, alongside a demanding day job and often with growing families. Fewer underwent the drastic mid-career financial challenge for the relative indulgence of full-time scholarship over three years. For those of us who undertook part-time study, many took significantly longer than the prescribed candidature tenure - a circumstance that would not be tolerated today.

Given the relative paucity of pre-existing $\mathrm{PhD}$ supervisors in-discipline, many had to look beyond their direct field for supervisory support, or accept inexperienced supervision. Many also naively studied at their host university, leading to conflicts of interest over research and teaching with their supervisors. Yesterday, my colleagues Angelo Karantonis and Garrick Small shared with you their cross-sectional analysis of the PRRES community (Karantonis and Small, 2006), which provided a background of our challenging state of play regarding PhDs. Of course, those of us with PhDs have, hitherto, been thrown into a supervisory role and examiner role moments after acceptance of our own testamur, without any real mentoring or experience beyond the limitations of our own doctoral supervisors. Lesson: there is scope for the PRRES doctoral sessions to include a forum for mentor support and exchange.

Imagine the reaction from certain of my colleagues a few months ago when our Pro-Vice Chancellor Research let it be known (albeit fifteen years post-Dawkins) that only those with a $\mathrm{PhD}$ would henceforth be considered as 'researchers', and then only subject to being 'research active' from an ARC / RQF perspective. Welcome to my world. The first 
statement effectively closed the door in the face of $40 \%$ of my colleagues, and the 'research active' rider sidelined another 30\%. Lesson: we are now playing under a very different set of rules.

\section{COLLABORATION, INDIVIDUALISM AND EXCELLENCE}

When I started writing this paper, I was going to assert that collaboration is the new individualism, and that the day of the individual research progressing their own agenda behind a closed door is history if we want to survive at academic departments. First reading of RQF (Commonwealth Department of Education Science \& Training, 2006) infers that collaboration (and especially transdisciplinary collaboration) is the new order. Reflecting on research presented at PRRES over the last fourteen years of my association, most is of a somewhat singular and independent nature (albeit that our changing times appear to be evolving from the 'give it a go' era to some examples of mentored coauthored masters and doctoral scholar submissions). Unfortunately, with limited exceptions few if any of our number, can provide examples of sustained cutting edge research grounded on major externally collaborative investigations that seek to answer our respective countries' national research priorities research fields, courses and disciplines (RFCD) and Socio-Economic Objectives (SOE). To the best of my knowledge only a handful (if that) of the PRRES community have seen an ARC grant through to fruition (and thus have that requisite track record that earns us the respect of the serious research community in our wider universities). Lesson: we are yet to prove our worth.

So how do we address the collaboration challenge? Most of the PRRES academic community were recruited by their respective universities because they bring different complementary teaching expertise to their colleagues. Thus, there may be one portfolio investment specialist in a team alongside a couple of valuers, perhaps a lawyer, planner, economist or two, the occasional statistician or construction specialist within any given team (albeit that several of the PRRES community 'teams' comprise fewer than four or five colleagues). Obviously, those individuals come from different professional and research backgrounds. However, just as the skills are complementary from a teaching perspective, so they can be also from a research viewpoint (if appropriately harnessed).

There is another aspect to collaboration as the new individualism, in these curious times when there is a supposed expectation that faculty members all need to be 'above average'. The emphasis of The Recommended $R Q F$, which was accepted by Cabinet in October 2006 (Commonwealth Department of Education Science \& Training, 2006), as the full title of the document implies, is on quality and impact. Reportage requires evidence of demonstrated collaborative activity - hence posturing to demonstrate something other than the individual. However, within the RQF our ability to demonstrate individual excellence is the driver that determines the overarching narrative of our collaboration. Lesson: In this exercise to be merely 'above average' is not enough; in this exercise we have to individually demonstrate sustained excellence over a six year period, and further 
demonstrate that collaboration provides a level of quality and impact that is greater than the sum of the parts.

\section{RESEARCH STRENGTHS}

I will elaborate on the challenge anecdotally. In August 2006, I was asked to facilitate what I will refer to as 'research strengths' posturing for the Schools of Design and Built Environment, within my Faculty. This was two months before the Recommended RQF was released, and thus we were operating on the 'Expected', rather than 'Recommended', $\mathrm{RQF}$. Similar exercises have, I realise, been going on in most of our universities. This is best witnessed by the unsuccessful professorial recruitment attempts at both QUT and Curtin, who strived to recruit senior academics with a demonstrable record of quality and impactful research before the audit date of 31 March 2007 (so that their record of achievement over the last six years would be credited to their new employer). Given the flurry of activity across the board to 'buy-in' five-star records of accomplishment with deferred start dates (afforded by leave without pay for perhaps the first six months), DEST closed the door on such strategising by changing the audit day for full-time employees to 31 December 2006.

My Pro-Vice Chancellor Research made the calculated decision to call for research strengths to identify them across the University. Research strengths, of course, are not School or Faculty specific. The historic structure of the academic School is as the most convenient way of administering the delivery of undergraduate teaching, as opposed to delivering research synergy. Flexibility became my byword. My anticipatory journey saw me momentarily as Director-designate of the Centre for the Creative City. There was logic to this, as an opportunity the Faculty to niche research in planning, construction, property and project management alongside the creative needs of design colleagues. However, those of you who know my flexibility realise that I do not have a proven sixyear record of accomplishment in creative city research.

Importantly, the initial process demonstrated synergies that allowed us to think much bigger, and investigate a Laboratory for the Contemporary City that cut across the whole university. It must be a good idea because RMIT as a counterpart ATN university in the CBD has been strategising along similar lines. This journey will unfold in the coming 12 -24 months. Despite perhaps thinking that research emanating out of our disciplines has an important influence on understanding the city, within our institutions we have colleagues in the established research disciplines who have been investigating the city for far longer than property and real estate programmes have been taught in universities. However, we do understand the notion of property better than many of our more research established peers from other faculties, so there is scope for invaluable collaboration and collegiality where we can contribute towards important city related issues. Such activity and exposure to a heritage of established research skills will facilitate co-mentoring doctoral scholars and help overcome concerns about research support. 


\section{QUALITY AND IMPACT}

Meanwhile, after several months where I was expected to engage in the power-plays of research strength posturing, like the Bunyip ${ }^{1}$ I have returned to the essential question, 'what am I?' Where can I demonstrate my four best quality research outputs and most significant impact over the last six-years for my RQF evidence portfolio? The answer is firmly in the field of property rights, which is how I amused myself for several years in the South Pacific. In taking over a built environment portfolio, I perceived that I should refocus the property rights into an investigation of the city as common property and brought together a transdisciplinary team of 11 active researchers to address aspects of urbanism, environment and health in the city. An understandable lack of demonstrable collaborative track record from this new team left this project unfunded. The positive outcome is that the scholars will each now contribute a chapter towards a monograph to demonstrate their synergy and collective expertise.

My demonstrated expertise is in property rights and leasehold analysis in developing countries and indigenous communities. My Pro Vice-Chancellor Research and Dean have now asked me to prioritise my own research agenda in this area, and to work with proven peer researchers only where collaboration is greater than the sum of the parts. How, you may ask, does this tie in with the ARC priorities? It is about being lateral: safeguarding Australia by investigating the relationship between democracy and property rights amongst Australia's close neighbours. It also ties in with the Land Management and Conflict Minimisation Project that I have assisted the Pacific Islands Forum Secretariat with, thus serving "industry" (in the form of the 16 member nation governments of the Forum Island Countries). This provides scope for an ARC Discovery Grant application in the first instance, with opportunities to collaborate towards an ARC Linkage Grant thereafter with the PIFS or individual governments.

The next challenge is how, and by whom, this activity will be assessed under the ARC and RQF. As property specialists with a hybrid background (as highlighted in Figure 1) that spans the built environment, humanities, law, economics and the social sciences we encompass aspects of Expert Panels 9-13. For my part, an investigation of the relationship between democracy and property rights is likely to be reviewed by a political scientist in the Social Sciences and Politics panel 9 (Political science, Policy and administration, Other policy and political science, Sociology, Anthropology, Human geography, Demography). At first sight not a collection of descriptors that we may normally associate with our research. From an impact perspective however, the argument is clear when governments are involved and Australia is left better informed in the ways of its immediate neighbours.

\footnotetext{
${ }^{1}$ Bunyip is derived from an aboriginal word relating to a mythical creature said to inhabit inland waterways. In this context, I draw on Jenny Wagners richly descriptive Bunyip of Berkeley's Creek, where the mythical creature illustrated by Ron Brooks seeks to find out 'what am I?'. Wagner, J. \& Brooks, R. (1990) The Bunyip of Berkeley's Creek, London, Puffin Books.
} 


\section{THE CHANGING ROLE OF PRRES}

Before closing, I am going to offer some specific guidance that may encourage further discussion on how PRRES can grow from strength to strength. This will need a change of thinking and engagement, as continuing on the current path may inevitably lead to its early demise. Given the currency of the RQF and our challenge in satisfying the expectations of our contemporary roles, I have not expanded my discussion into 'tired' research / teaching debate (Barnett, 2005) or the pedagogy opportunities surrounding the Bologna Accord (Commonwealth Department of Education Science \& Training, 2006b). My view on the research /teaching continuum in an earlier paper (Boydell, 2006) to our sibling organisation AUBEA, summarises some of the extensive literature in that area. Bologna is a reality and one that is being considered by senior management in our respective institutions, and our colleagues from the University of Melbourne can better advise on their unfolding solution.

For PRRES to endure and grow, in our output driven environment it is important that our participation has tangible benefits for our employers and sponsors. We have to avoid the trap that I feel the Property Council run the risk of falling into by providing "professional development designed for industry professionals by industry leaders" (PCA, 2006). Industry leaders are not necessarily good educators, just as good educators are rarely industry leaders. This is an example of industry believing that it knows what is best for industry, rather than being open to seeking intellectual support and guidance from academe. Similarly, academe could be criticised for paying lip service to their industry advisory panels and professional accreditation processes. Likewise, academe runs the risk of operating in a quality and impact driven vacuum, believing we know best, and failing to value the identified needs of society (although the ARC guides us on those) and the actual needs of the profession. From an industry perspective "individual scholars pursuing their passionate interests increasingly risk labels such as 'irrelevant', 'elitist', 'out-of-touch' and 'marginal'” (Furedi, 2004).

It is far easier to criticise than to act. By way of solution, we must better communicate and collaborate with our major sponsors like the Australian Property Institute and the Royal Institution of Chartered Surveyors, together with the Property Council and Government, to develop knowledge in our discipline. We actually need one another to ensure survival and growth, rather than merely being partnerships of convenience. PRRES has the potential to make a tangible difference if we combine our collective imagination towards tackling and debating the key property related issues as collaboratively perceived. I would like to challenge the PRRES Board with this task so that very early calls for papers for subsequent conferences will systematically call for focussed papers on at least one day of the programme, tackling specific themes where we can start to make a difference and be relevant. Such a forum can plant the seeds for future ARC Linkage Grants and even, in time, a Cooperative Research Centre to enhance the collaboration between researchers, industry and government that improves efficiency in the use of intellectual and research resources. 
Critical to proving the relevance of research and justifying the time spent developing it is making it accessible. PRRES has the tools to expose research to the broader community with a dedicated website and the Pacific Rim Property Research Journal. Whilst the journal is included in the DEST list, it does not count for RQF purposes, as it is not widely accessible and has a limited distribution. As a result, it fails to merit inclusion in the ISI Web of Science citation index that becomes one of our new auditing tools which leaves all of us rather exposed. This being the case, henceforth there is little benefit for any of us to seeking to publish in a journal that does not count. Again, I offer a solution that could make a difference by the second RQF audit in 2012. That is for PRRES to place itself in the Creative Commons and operate as an openly accessible electronic journal. Several of our universities have established an e-press, including my own. I have detailed the requirements to the Editorial Chairman and the incoming President in anticipation that they will act to ensure the currency of the journal by significantly enhancing its international distribution and accessibility in this digital age.

\section{CONCLUSION}

We live in fast changing times. "There is no agreed-upon answer - and the point is there doesn't need to be. We can live together without agreeing on what the values are that make it good to live together; we can agree what to do in most cases, without agreeing about why it is right" (Appiah, 2006). Corden hoped that enlightenment is the outcome of controversy (Corden, 2005). I have taken the opportunity to share several lessons and make several suggestions. If, during this conversation, I have challenged your values or said anything controversial, then there is some hope for us both as researchers and for PRRES as a continuing forum of worthy exchange.

Whilst it can be easier to be reactive to change in the short term, in the long-term recalcitrance is a more painful response than embracing the ongoing dynamic and inevitable change that affects the university, the profession, industry and society. We should be impatient for change and "anxious to se the discipline move ahead to realise its full potential to contribute to society positively, constructively, and inspirationally" (Roulac, 2001). Furedi reminds us that "education involves challenging peoples perceptions of themselves, calling into question their common sense, and at its best, demanding that they become something other than what they once were" (Furedi, 2004). Down by the billabong that is academe, we are all still seen as bunyips in the eyes of some. We are not yet that which we must soon become. As property researchers, we need to move beyond being wrongly perceived as mythical creatures in a hypothetical world. In recent years, we have made many small steps in the right direction. We must now make confident strides.

\section{REFERENCES}

ABS (1998) 1297.0 - Australian Standard Research Classification (ASRC). Australian 
Bureau of Statistics, Accessed: 30/06/05, ABS Website, Available at:

http://www.abs.gov.au/AUSSTATS/abs@.nsf/Lookup/1297.0Main+Features11998?Ope Document.

Appiah, K. A. (2006) Cosmopolitanism: Ethics in a World of Strangers, London, Allen Lane / Penguin.

ARC (2006) Strategic Plan 2006-2008.

Barnett, R. (2005) Introduction. IN BARNETT, R. (Ed.) Reshaping the University: New Relationships between Research, Scholarship and Teaching. Maidenhead, Society for Research into Higher Education \& Open University Press.

Boydell, S. (2006) The Reality of Research: Multiple Expectations on the Contemporary University Serving the Construction Sector. Keynote Address at the Australasian Universities Building Educators Association (AUBEA) Conference, RUNESON, G. \& BEST, R., University of Technology Sydney.

Boyer, E. L. (1990) Scholarship reconsidered: priorities of the professoriate, San Francisco, The Carnegie Foundation for the Advancement of Teaching.

Coady, T. \& Miller, S. (1993) Australian higher education and the relevance of Newman. Australian Universities Review, 36, 2, pp. 40-44.

Commonwealth Department of Education Science \& Training (2006) Research Quality Framework - Assessing the quality and impact of research in Australia: The Recommended RQF. October 2006.

Commonwealth Department of Education Science \& Training (2006b) The Bologna Process and Australia: Next Steps. April 2006.

Corden, M. W. (2005) Moscow, Markets, or Trust: the Uncertain Future of Australian Universities. 4th Annual Sir Leslie Melville Lecture in the ANU Toyota Public Lecture Series, 21 September 2005. Australian National University.

EAG (2005) Research Quality Framework: Assessing the quality and impact of research in Australia. Final advice on the preferred RQF model. Endorsed by the Expert Advisory Group for the RQF. Commonwealth of Australia, Accessed: 30/06/06, 32, PDF, Available at: http://www.dest.gov.au/NR/rdonlyres/1A7E21B1-9C74-4AD8-9C8A FFED7688A32B/9798/Final_Advice_Paper.pdf.

Furedi, F. (2004) Where have all the intellectuals gone? Confronting 21st Century Philistinism, London, Continuum. 
Karantonis, A. \& Small, G. (2006) A Profile of Property Economics Academics and the maturation of the academic discipline. PRRES Conference, Fremantle, WA.

McCaffer, R. (2005) Research Assessment - the Emerging Experience. The Queensland University of Technology Research Week International Conference in collaboration with COBRA, AUBEA and CIB, SIDWELL, A. C., Brisbane, QUT.

McDonald, S. (2006) Reducing the risk factor. Property Australia, vol.21, 3, pp. 22-24.

Nillsen, R. (2004) Don't do what Australia has done. Quadrant, XLVIII, 11 - November. OECD (2002) Frascati Manual: The Measurement of Scientific and Technological Activities. Proposed Standard Practice for Surveys on Research and Experimental Development. Organisation for Economic Co-operation and Development, Accessed: 30/06/06, Web PDF, Available at: http://www1.oecd.org/publications/e book/9202081E.PDF.

PCA (2006) Advert for Property Council Professional Development. Property Australia, vol.21, 2.

Ramsden, P. (1998) Learning to Lead in Higher Education, London Routledge.

Roulac, S. (2001) Stephen Roulac on Place and Property Strategy, San Rafael, CA, Property Press.

Rowe, A. P. (1960) If the gown fits, Melbourne, Melbourne University Press.

Runeson, G. \& Skitmore, M. (1999) Writing Research Reports: a Practical Guide for Students of the Built Environment, Geelong, Deakin University Press.

Salt, B. (2006) The academic's lament. Property Australia, vol.21, 3, p.72.

Saunders, M. (2006) The Madness and Malady of Managerialism. Quadrant, L, 3 March, pp. 9-17.

Wagner, J. \& Brooks, R. (1990) The Bunyip of Berkeley's Creek, London, Puffin Books. 